\title{
The Postsecondary Education Pathways of Canadian Immigrants: Who Goes and How Do They Get There?
}

\author{
Pierre Canisius Kamanzi ${ }^{1}$, Tya Collins ${ }^{1}$ \\ ${ }^{1}$ Faculty of Education, University of Montreal, Canada \\ Correspondance: Pierre Canisius Kamanzi, Faculty of Education, University of Montreal, Pavillon Marie-Victorin, \\ bureau A-511, C.P. 6128, succursale Centre-ville, Montreal, Quebec, Canada H3C 3J7.
}

Received: December 18, 2017

Accepted: January 9, 2018 Available online: January 18,2018

doi:10.11114/ijsss.v6i2.2866

URL: https://doi.org/10.11114/ijsss.v6i2.2866

\begin{abstract}
This article aims to describe and understand the postsecondary education pathway morphology of Canadian youth from the province of Quebec with immigrant family origins, as well as the factors that contribute to its structuration. Results from a subsample of 20,387 students reveal that they generally acces postsecondary education and follow a linear pathway at higher rates than their peers whose parents were born in Canada. However, significant differences exist between first and second-generation immigrants, as well as when parental geographic region of origin is considered. In conclusion, several possible interpretations are proposed.
\end{abstract}

Keywords: higher education, academic pathways, academic success, mmigrants

\section{Introduction}

Despite equal educational opportunities in developed countries, many studies underscore important disparities between students from immigrant backgrounds and their native-born peers. In many cases, relatively weaker academic results can be associated to the former in comparison to the latter when it comes to basic education (elementary and secondary) (Crul, Schneider \& Lelie, 2012; Dustmann, Frattini \& Lanzara, 2011; Schnepf, 2007). While some immigrant youth manage to finish high school, which is mandatory in many countries, the majority of immigrant students are forced to halt their academic endeavors due to the selective nature of the educational tracks leading to higher education (Baum \& Flores, 2011; Griga \& Hadjar, 2013). In many countries, the selection process and early academic guidance are laid out in such a way that only a minority is able to access a program or institution leading to higher education. Contrastingly, the majority is relegated to short-term vocational programs aimed at labour force integration and thus, disssolving an academic career (Crul, Schnell, Herzog-Punzenberger, Wilmes, Slootman \& Gómez, 2012). The situation varies from one educational system to another, not only in terms of the academic pathway structure established by public policies in education (Pechar \& Andres, 2011), but also by immigration policies that may advance or inhibit immigrant academic and social integration (Boyd, 2002; Koopmans, 2010).

This study examines the situation in the province of Quebec, in Canada. Generally speaking, Canadian youth from immigrant backgrounds are more likely to access postsecondary studies than their native-born peers (Finnie \& Mueller, 2010; Picot, 2012). However, this situation varies greatly when geographic regions of origin are considered. Youth with parents from Sub-Saharan Africa, the Caribbean, Central America, and South America have a lower graduation rate and a higher dropout rate in high school (Mc Andrew, Ledent, Murdoch, Ait-Said \& Balde, 2013). Even though many persevere to university, few graduate despite their high postsecondary aspirations (Kamanzi \& Murdoch, 2011). This article analyzes the pathways undertaken by youth from various immigrant communities in Quebec with the intent of pinpointing the mechanisms leading to access and perseverance inequalities in postsecondary education. From this perspective, their pathways (progression) and the geographical origins of their parents are compared.

This article is divided into five sections. The first advances an analytical framework based on the pathway concept which suggests that simplifying admission requirements through postsecondary pathway diversification would contribute to expanding its democratization. The second highlights the relative influence of public policies and the organization of educational systems on the pathways of immigrant students. The third, « methodology », describes the data that was utilized, the variables that were examined, and the analysis strategies that were adopted. In the fourth section, the results are presented and interpreted. Finally, the discussion and conclusion summarize the results and 
suggest several possible interpretations.

\section{Educational Systems and Pathway Variability in Postsecondary Education}

All educational systems are organized in stages, which are divided into educational tracks and curricula. While the progression from elementary to high school occurs automatically and mandatorily, the same is not applicable in the passage from high school to college. In fact, not only is it conditional to students' decisions, but it also rests heavily on the students' academic track or program in high school, as well as their demonstrated academic abilities. As such, high schools are divided into general and vocational tracks. The former enables access to higher education, while the latter sets the stage for exiting the school system and entering the labour force. As stated by Picard, Trottier \& Doray, "educational systems consist of a regulated, and inevitably, linear itinerary encompassing the academic pathway from elementary school to postsecondary education up until graduation" $(2011: 3)$.

Reasearchers who have conducted studies within various social contexts have denounced the fact that the placement of students within these two types of tracks reflects social inequalities mediated by academic performances and aspirations (Duru-Bellat, Kieffer \& Reimer, 2010; Felouzis, 2014). Hence, when children from affluent families are streamed into general tracks and their peers from low-income families to vocational ones, high school becomes a place of social segregation (Lucas, 2001), and postsecondary education becomes an instrument for social inequality production and reproduction (Alon, 2009; Duru-Bellat, Kieffer \& Reimer, 2010). This is reinforced by the mobilization and interaction of different types of capital (cultural, social and economic) which play to the advantage of middle and upper class families (Lynch \& O'riordan, 1998).

In order to minimize this form of segregation which affects students from underprivileged backgrounds (mainly ethnocultural minorities from immigrant origins) (Barrett \& Maître, 2013; Dustmann, Frattini \& Lanzara, 2011), many countries have established policies to provide greater flexibility in admissions processes (Picard et al., 2011). These policies aim to diversify and individualize educational pathways, notably by offering a better link between secondary vocational and postsecondary education, thus increasing the possibility of postsecondary access while addressing the growing social demand for education (Hoelscher, Hayward, Ertlet \& Dunbar-Goddet, 2008; Maclean \& Pavlova, 2013).

This educational trajectory restructuration has resulted in the multiplication of linear and non-linear pathways. The former can be characterized as a continuous trajectory to postsecondary education and thus standardized, while the latter, a discontinuous trajectory involving bifurcations often in the form of some combination of vocational training and general education. However, the importance and effect of these policies on the democratization of postseondary education seem to vary considerably depending on the educational system and the public policies that shape them (Kamanzi, Guégnard, Imdorf, Koomen \& Murdoch, 2014; Murdoch, Guégnard, Koomen, Imdorf, Kamanzi \& Meyer, 2017), as we will attempt to demonstrate in the following section.

\section{Youth from Immigrant Backgrounds and the Provision of Educational Pathways within Educational Systems}

The integration of immigrants is strongly influenced by the ideological perspectives within public policies of the host society. Without claiming that there is an absolute relationship of cause and effect, the chances of integration of immigrants are all the greater when the host country is open to multiculturalism and interethnic exchanges, and through these principles, aims to reinforce social cohesion (Koopmans, 2010). On the other hand, this integration tends to be fragile if public policies are rigid and guided by the desire to preserve monoculturalism and compulsory assimilation by tightening the conditions for immigration, access to citizenship, and the rights inherent to it. However, multiculturalism is not synonymous with integration, as it can be indexed to the marginalization of some immigrant communities because of perceived cultural differences or reified physical traits in social representations (Cutler, Glaeser \& Vigdor, 2007; Li, 2003). Ultimately, it all depends on the local realities and practical actions mobilized to promote social cohesion (Koopmans, 2010), as well as the relationships between the host society and immigrants, and the sense of belonging that they forge (Phinney, Horenczyk, Liebkind \& Vedder, 2001;Zulfikar, 2016).

In this regard, several studies in Canada show that, unlike many other countries, young people from immigrant backgrounds perform at a comparable level to their peers from non-immigrant families (Hochschild \& Cropper, 2010; Rothon, Heath \& Lessard-Phillips, 2009). Furthermore, they pursue postsecondary education at a relatively higher proportion than the latter (Finnie \& Mueller, 2008, 2010; Kamanzi, Bastien, Doray \& Magnan, 2016; Picot, 2012; Thiessen, 2009). However, a closer examination of the issue has shown significant disparities among immigrants depending on their ethnocultural and geographic origins. In fact, different pathway profiles were found depending on the students' parental region of origin. While youth having parents who immigrated from Europe and Asia exhibit exceptional pathways, the situation is reversed for their peers whose parents are from the Caribbean and Latin America (Abada, Hou \& Ram, 2009; Kamanzi et al., 2016, Thiessen, 2009).

At the provincial level, the results from Quebec are similar, yet slightly different (Mc Andrew, 2015; Mc Andrew et al., 
2013). Studies indicate that, in general, the educational pathways of youth from immigrant backgrounds are fairly comparable to those of their peers whose parents were born in Quebec (and in Canada), while highlighting significant disparities between communities. On one hand, youth whose parents are from European, Asian or Arab countries have comparable or even better educational pathways compared to their Canadian-born peers. Conversely, those whose parents come from the Caribbean, Sub-Saharan Africa, Central America, South America, and South Asia have success rates lower than the provincial average. Moreover, their grade repetition and dropout rates are higher. This results in significant gaps pertaining to access and perseverance in postsecondary education.

In order to better understand the production of inequalities over time, this article proposes to describe the academic pathway morphology of young Quebeckers from immigrant backgrounds. In other words, who goes to postsecondary education and how? More specifically, we will examine the extent to which those who access postsecondary education undertake linear or nonlinear pathways. Beforehand, the data, variables, and analysis employed in the study will be described.

\section{Methodology}

\subsection{Data Source and Sample}

The data used in this article come from the administrative file of the Quebec Ministry of Education, Recreation and Sports. The sample is composed of 47749 students from two cohorts entering their first year of high school in 1994-1995 ( $\mathrm{N}=23,665)$ and 2002-2003 $(\mathrm{N}=24,084)$ respectively. In both cases, the subsample represents $25 \%$ of the cohort. The analysis shows that $95 \%$ of students of immigrant backgrounds in this sample lived in the city of Montreal and its suburbs, the most populous municipality in the province of Quebec, and the second-most populous in Canada. To avoid socioeconomic and geographic bias, the analysis will be limited to students whose parents lived in this region, for a better comparison with their peers whose parents are Canadian-born. The selected subsample (see table 1) is composed of 20,387 students which includes 5,334 (26\%) with at least one parent who is a first-generation immigrant, that is, who was born abroad. The database contains longitudinal data which facilitate the study of their academic pathways over a ten-year period. It also contains information on certain sociodemographic and academic characteristics allowing for the analysis of these pathways.

Table 1. High school sociodemographic and academic characteristics of the subsample

\begin{tabular}{|c|c|c|c|c|c|}
\hline & $\begin{array}{l}\text { Assigned a } \\
\text { special } \\
\text { education } \\
\text { code }\end{array}$ & $\begin{array}{c}\text { Educational delay: } \\
\text { entered high school at } \\
\text { age } 13 \text { or over }\end{array}$ & $\begin{array}{l}\text { Attended a } \\
\text { private } \\
\text { school }\end{array}$ & $\begin{array}{l}\text { Lives in a neighbourhood } \\
\text { where the income is lower } \\
\text { than the regional median }\end{array}$ & $N$ \\
\hline & $\%$ & $\%$ & $\%$ & $\%$ & \\
\hline \multicolumn{6}{|l|}{$\begin{array}{l}\text { Parental geographic } \\
\text { origin }\end{array}$} \\
\hline Canada & 11 & 17 & 27 & 30 & 15,053 \\
\hline $\begin{array}{l}\text { Only one parent } \\
\text { born in Canada }\end{array}$ & 13 & 17 & 25 & 49 & 1,678 \\
\hline East Asia & 6 & 37 & 39 & 64 & 211 \\
\hline $\begin{array}{l}\text { Southeast Asia and } \\
\text { the Pacific Islands }\end{array}$ & 9 & 38 & 16 & 80 & 656 \\
\hline $\begin{array}{l}\text { North Africa and the } \\
\text { Middle East }\end{array}$ & 9 & 30 & 36 & 63 & 762 \\
\hline Sub-Saharan Africa & 18 & 42 & 14 & 73 & 158 \\
\hline $\begin{array}{l}\text { Europe and } \\
\text { English-speaking } \\
\text { countries }\end{array}$ & 10 & 2 & 27 & 65 & 737 \\
\hline $\begin{array}{l}\text { Latin America and } \\
\text { the Caribbean }\end{array}$ & 18 & 44 & 19 & 77 & 1,132 \\
\hline Total & 11 & 20 & 26 & 40 & 20,387 \\
\hline
\end{tabular}

The dependent variable at the heart of this article is the educational pathway to postsecondary education (college or university). It was measured by the path taken during and after high school. The database that was used allows for the identification of students who attained postsecondary education in college and, among them, those who attended uni versity. In addition, it is possible to distinguish between those who followed a linear path and those who took a non-linear path to access college. Linear pathways include students who, after graduation from high school, began postsecondary education at the college level. Conversely, non-linear pathways include those who, after graduation, enrolled in a parallel program or equivalent. More specifically, these are individuals who, after graduation from a high school vocational program, have undertaken studies in a general education program and vice versa. These 
considerations make it possible to form the following four categories of students:

1) Non-access to higher education: those who, after high school, have left school (at least for the period of observation);

2) Linear pathway ending in college: those who, after obtaining a high school diploma in general education, went to a college in a technical or pre-university program, but did not pursue university studies;

3) Linear pathway to university: those who entered university after obtaining a college diploma and continued their studies in university;

4) Non-linear pathway ending in college: those who, before enrolling in a college, completed dual training in high school (general and vocational), but did not continue to university.

The independent variable is the geographic origin of the students' parents. It was measured by the country of birth of both parents. In order to reach sufficient numbers for analysis, countries were grouped by geographic region. Inspired by categorizations put forth by previous Canadian studies (Finnie \& Mueller, 2008; Thiessen, 2009; Kamanzi et al., 2016), students were grouped into eight categories: (1) Canada ( $\mathrm{N}=15,053)$, (2) mixed: one parent born in Canada, the other born abroad (N=1,678), (3) Europe and Anglo-Saxon countries (N=737), (4) East Asia (N=211), (5) Southeast Asia and the Pacific Islands ( $\mathrm{N}=656),(6)$ North Africa and the Middle East (N=762), (7) Sub-Saharan Africa (N=158), (8) Latin America and the Caribbean $(\mathrm{N}=1,132)$.

The control variables. Three variables linked to secondary schooling having a significant influence on academic pathways, revealed in the preliminary analyses were included: (1) type of high school attended (private or public), (2) educational delay and (3) special education code (student files contain the age at which they entered their first year of high school as well as a code that indicates whether they've had learning or adjustment difficulties or disabilities). Additionally, two sociodemographic variables were also taken into account: gender and the socioeconomic background of the students. The latter is measured by two indicators related to the characteristics of parents' place of residence (census unit): (1) The percentage of university graduates and (2) the median income per household. These two variables were derived from the 2006 Canadian census data. Table 1 describes the distribution of the subsample with respect to these variables. As shown, there are relatively significant differences concerning these variables when parental geographic region of origin is considered.

\subsection{Statistical Analysis Strategies}

Firstly, descriptive analyses were carried out in order to obtain a global portrait of the academic pathways to postsecondary education, in accordance to the independent variable. Next, multinomial analyses (Allison, 2003) were performed taking into account the three control variables described in the previous subsection. Four probabilities associated to the dependent variable categories will be compared: (1) $\mathrm{p}(\mathrm{y}=0)$ : no access to higher education (reference catgory), (2) $\mathrm{p}(\mathrm{y}=1)$ : linear pathway ending in college, (3) $\mathrm{p}(\mathrm{y}=2)$ : linear pathway to university, and $(4) \mathrm{p}(\mathrm{y}=3)$ : non-linear pathway ending in college.

Statistically, the purpose of the analysis is to estimate the influence of the students' parental geographic origin on the probability of undertaking one pathway or another, under the effects of factors $X_{1}, X_{2}, \ldots X_{k}$. The logit function model makes it possible to compare the probability associated with each of the pathways with that of the inverse (that is to say, not accessing postsecondary studies or $\mathrm{p}(\mathrm{y}=0)$ ). To facilitate interpretation, marginal effects are presented instead of regression coefficients or odds ratios. For each pathway analyzed, a coefficient (marginal effect) with a value equal to or close to 0 indicates that students from immigrant backgrounds are as likely to undertake a given pathway as their non-immigrant peers (reference category). Yet a coefficient with a value higher than 0 indicates that the former are more likely to follow a given pathway, while a value lower than 0 indicates the opposite.

\section{Presentation of Results}

After high school, the majority of Quebec youth continue to postsecondary studies. As shown in chart 1, ten years after beginning high school, around the age 22, two out of three students from Quebec (65\%) whose parents reside in the Montreal area or suburbs had attended a postsecondary institution at some point in time. Among these, $35 \%$ had ended their studies after college and $30 \%$ had gone on to university. However, the rate of access to postsecondary education, varies among students according to the geographic origin of their parents. It is significantly higher among youth with families from East Asia (80\%), North Africa and the Middle East (74\%), but relatively lower among those from Latin America and the Caribbean (58\%). 


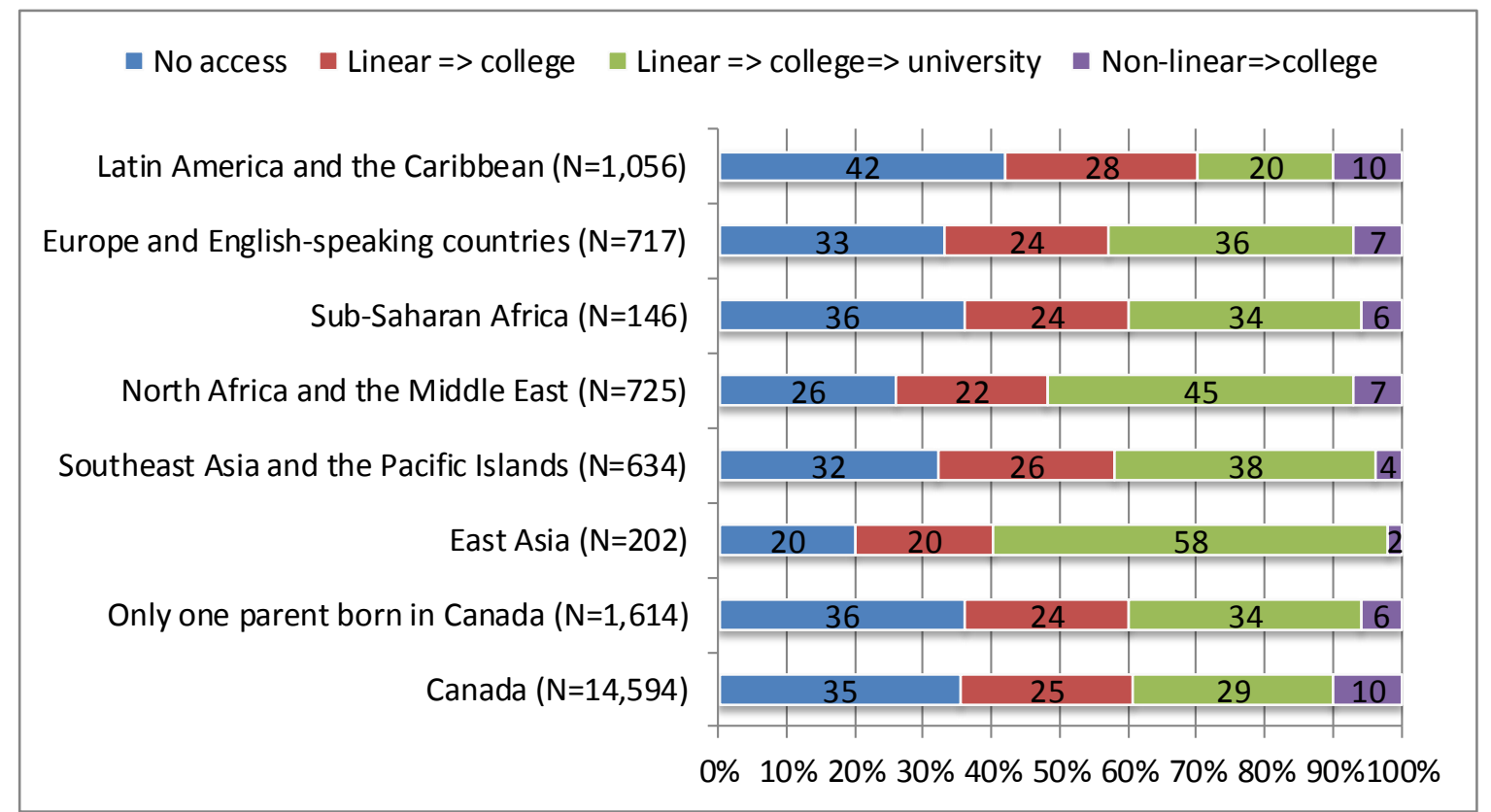

Chart 1. Pathways to postsecondary education by parental geographic origin and the type of pathway undertaken to postsecondary education $(\%)$

In addition to the highest level of education (college or university), students are distinguished by the type of pathway undertaken. According to the analysis of our sample, $56 \%$ of students follow a linear pathway; $25 \%$ go from high school to college; and $31 \%$ from high school to college, and then university. Contrastingly, almost one out of ten students (9\%) accesses college via a non-linear pathway. This category is composed of students who, after obtaining a high school diploma in a vocational training program, had undertaken courses in a general education program and vice versa, before going college. However, further analysis reveals that the majority is composed of vocational training graduates who subsequently took courses in general education to be eligible for college.

While it may appear that the choice to follow a linear or non-linear pathway depends on student decisions, results reveal significant differences when parental geographic origin is considered. Overall, with the exception of those who come from Latin America and the Caribbean (10\%), students from immigrant backgrounds are less likely to undertake a non-linear pathway compared to their peers whose parents are Canadian-born (10\%). For example, the proportion is relatively low among those whose parents come from East Asian countries (2\%), as well as those from South Asia and the Pacific Islands (4\%). In contrast, students from immigrant families follow a linear pathway to university in a relatively higher proportion than their peers with Canadian-born parents at 29\%, compared to 58\% for those from East Asia, 45\% from North Africa and the Middle East, 38\% from Southeast Asia, 36\% from Europe and Anglo-Saxon countries, and 34\% from Sub-Saharan Africa. Nevertheless, the situation seems generally similar for those who follow a linear pathway to college without pursuing university; the analysis shows that there is little difference in this regard.

In order to estimate the relative influence of the parental geographic origins of students from immigrant backgrounds on the educational pathway to postsecondary education, multinomial logistic analyses (table 2) were performed by comparing them to their peers whose parents are Canadian-born (reference category). The analysis was organized in two models. Model 1 includes only the parental geographic origin, while model 2 controls for socio-demographic and academic variables. For each category, we also distinguish between first-generation and second-generation immigrants.

The results of model 1 clarify those of the descriptive analysis (chart 1), indicating a presence of significant differences for linear and, to a lesser extent, non-linear pathways. Immigrants are more likely to undertake linear pathways. Conversely, they are less likely to undertake non-linear pathways.

When it comes to linear pathways, a careful analysis of the results reveals three main findings. Firstly, the differences are much higher in uni versity compared to college. Secondly, the situation varies greatly among immigrants according to whether they are first or second-generation immigrants. However, it is noteworthy that immigrants from the Caribbean and Latin America are an exception: they are less likely than others to follow a linear pathway to uni versity. Thirdly, significant differences are relatively higher among second-generation immigrants compared to their first-generation peers. Thus, compared to non-immigrants, the probability difference in percentage of following a 
linear pathway is 33\% among second-generation immigrants from East Asia, 25\% from North Africa, 22\% among those from Sub-Saharan Africa and 21\% from South-East Asia and the Pacific Islands.

With respect to non-linear pathways, the situation is somewhat reversed. As noted above, with the exception of those from Latin America and the Caribbean, immigrants are less likely to follow these pathways. As such, the analysis also makes it possible to draw two observations. Once again, significant differences observed are variable according to the parental geographic origin of the students, but mainly for first-generation immigrants. Secondly, the situation is rather comparable between those of second-generation immigrants and non-immigrants.

Table 2. Multinomial regression coefficients - Average marginal effects

\begin{tabular}{|c|c|c|c|c|c|c|}
\hline & \multicolumn{3}{|l|}{ Model 1} & \multicolumn{3}{|l|}{ Mode2 } \\
\hline & $\begin{array}{l}\text { (1) Linear } \\
\Rightarrow \text { college }\end{array}$ & $\begin{array}{l}\text { (2) Linear } \Rightarrow \text { college } \\
\Rightarrow \text { university }\end{array}$ & $\begin{array}{l}\text { (3) Non-linear } \\
\Rightarrow \text { college }\end{array}$ & $\begin{array}{l}\text { (1) Linear } \\
\Rightarrow \text { college }\end{array}$ & $\begin{array}{l}\text { (2) Linear } \\
\Rightarrow \text { college } \\
\Rightarrow \text { university }\end{array}$ & $\begin{array}{l}(3) \\
\text { Non-linear } \\
\Rightarrow \text { college }\end{array}$ \\
\hline & $\mathrm{dy} / \mathrm{dx}$ & $\mathrm{dy} / \mathrm{dx}$ & $\mathrm{dy} / \mathrm{dx}$ & $\mathrm{dy} / \mathrm{dx}$ & $\mathrm{dy} / \mathrm{dx}$ & $\mathrm{dy} / \mathrm{dx}$ \\
\hline \multicolumn{7}{|l|}{ Parental geographic origin } \\
\hline Canada (reference) & .000 & .000 & .000 & .000 & .000 & .000 \\
\hline $\begin{array}{l}\text { Only one parent born in Canada } \\
\text { East Asia }\end{array}$ & $-.012(\mathrm{~ns})$ & $.040 * *$ & $-.032 * * *$ & $.001(\mathrm{~ns})$ & $.024^{*}$ & $-.028 * * *$ \\
\hline $2^{\text {nd }}$ generation & $-.023(\mathrm{~ns})$ & $.329 * * *$ & $-.035(\mathrm{~ns})$ & $.001(\mathrm{~ns})$ & $.271 * * *$ & $-.022(\mathrm{~ns})$ \\
\hline $1^{\text {st }}$ generation & $-.058(\mathrm{~ns})$ & $.269 * * *$ & $-.091 * * *$ & $-.029(\mathrm{~ns})$ & $.266^{* * *}$ & $-.087 * * *$ \\
\hline \multicolumn{7}{|c|}{ Southeast Asia and the Pacific Is lands } \\
\hline $2^{\text {nd }}$ generation & $.020(\mathrm{~ns})$ & $.210 * * *$ & $-.047 * * *$ & $.036(\mathrm{~ns})$ & $.164 * * *$ & $-.043 * *$ \\
\hline $1^{\text {st }}$ generation & $-.016(\mathrm{~ns})$ & $-.039(\mathrm{~ns})$ & $-.065 * * *$ & $.051(\mathrm{~ns})$ & $.125^{* * *}$ & $-.063 * * *$ \\
\hline \multicolumn{7}{|l|}{ North Africa and the Middle East } \\
\hline $2^{\text {nd }}$ generation & $-.050^{*}$ & $.251 * * *$ & $-.019(\mathrm{~ns})$ & $-.017(\mathrm{~ns})$ & $.137 * * *$ & $-.004(\mathrm{~ns})$ \\
\hline $1^{\text {st }}$ generation & $-.022(\mathrm{~ns})$ & $.084 * * *$ & $-.027 *$ & $.008(\mathrm{~ns})$ & $.118^{* * *}$ & $-.022(\mathrm{~ns})$ \\
\hline \multicolumn{7}{|l|}{ Sub-Saharan Africa } \\
\hline $2^{\text {nd }}$ generation & $-.099(\mathrm{~ns})$ & $.216^{* *}$ & $.081(\mathrm{~ns})$ & $-.075(\mathrm{~ns})$ & $.182 *$ & $.089(\mathrm{~ns})$ \\
\hline $1^{\text {st }}$ generation & $.017(\mathrm{~ns})$ & $-.024(\mathrm{~ns})$ & $-.078 * * *$ & $.082(\mathrm{~ns})$ & $.070(\mathrm{~ns})$ & $-.076 * * *$ \\
\hline \multicolumn{7}{|l|}{ Europe/anglo-saxon countries } \\
\hline $2^{\text {nd }}$ generation & $.022(\mathrm{~ns})$ & $.062 *$ & $-.029 *$ & $.029(\mathrm{~ns})$ & $.061(\mathrm{~ns})$ & $-.019(\mathrm{~ns})$ \\
\hline $1^{\text {st }}$ generation & $-.063 * *$ & $.074 * *$ & $-.028 *$ & $-.023(\mathrm{~ns})$ & $.080 * *$ & $-.017(\mathrm{~ns})$ \\
\hline \multicolumn{7}{|l|}{ Latin America and the Caribbean } \\
\hline $2^{\text {nd }}$ generation & $.075 * * *$ & $-.053 * *$ & $.006(\mathrm{~ns})$ & $.112(\mathrm{~ns})$ & $-.033(\mathrm{~ns})$ & $.005(\mathrm{~ns})$ \\
\hline $1^{\text {st }}$ generation & $-.033(\mathrm{~ns})$ & $-.160 * * *$ & $-.006(\mathrm{~ns})$ & $.060(\mathrm{~ns})$ & $-.049 *$ & $.008(\mathrm{~ns})$ \\
\hline Pseudo- $\mathrm{R}^{2}$ & .0096 & & & .1209 & & \\
\hline L.R. chi2 & $419.19 * * *$ & & & $5,974.44 * * *$ & & \\
\hline D.F. & 39 & & & 57 & & \\
\hline $\mathrm{N}$ & 19,688 & & & 19,097 & & \\
\hline
\end{tabular}

Notes:

- $\mathrm{p}<.05 ; * * * \mathrm{p}<.01 ; * \mathrm{p}<.001 ; \mathrm{ns}$ : not significant at $\mathrm{p} .05$

- Model 1: Parental geographic origin.

- Model 2: Parental geographic origin, special education code, educational delay, type of high school (public/private), neighbourhood household income, \% of university graduates in the family neighbourhood, and gender.

Model 2 takes into account control variables related to academic and socio-demographic characteristics. The results reveal that these variables exert a significant influence on access to higher education and the undertaking of different pathways. However, in order to facilatate the interpretation of results, only the coefficients associated to the independent variable (parental geographic origin) are presented. The introduction of these two categories of variables significantly modifies the influence of the parental geographic origin of the students, indicating that with comparable academic and socio-demographic characteristics, immigrants are significantly more likely to pursue postsecondary education at the college and university levels via linear pathways, regardless of generational status (first or second). However, an additional analysis reveals, that this change in results is more attributable to student academic characteristics than to socio-demographic ones, which supports the hypothesis that the quality of the students' academic record is strongly linked to the type of pathway they undertake, namely a linear one. Yet, the introduction of these variables does not reveal significant differences in non-linear pathways, which supports the opposite hypothesis that such pathways are borrowed by students with lower quality academic records.

\section{Discussion}

While international studies recognize the fact that immigrants are often victims of segregation (Levels, Dronkers $\&$ 
Kraaykamp, 2008; Crul et al., 2012; Söhn \& Özcan, 2006), or even complete exclusion in certain contexts like France (Felouzis, Liot \& Perroton, 2005), Germany, Belgium, Austria and Hugary (Jenkins, Micklewright, \& Schnepf, 2008; Riedel, Schneider, Schuchart \& Weishaupt, 2010) or the USA (Ellen, O'Regan, Schwartz, Stiefel, Neal, \& Nechyba, 2002), three complementary explanations have been put forth to explain the exception in Canada. The first refers to immigrant youth's high educational aspirations (Finnie, Muller, 2008, Taylor \& Krahn, 2005, Thiessen, 2009), but also to those of their parents who invest significant resources, often sacrificing beyond their means to make postsecondary education accessible for their children (Anisef, Brown \& Sweet, 2011). The second is that the aspirations of Canadian immigrant youth align with their elementary and secondary school pathways. Overall, the academic results of students from immigrant families and their peers from Canadian-born families are similar (Hochschild \& Cropper, 2010). The third refers to the somewhat unique characteristics of Canadian immigration policies. This can be broken down into two hypotheses. First, the fact that Canadian immigrant youth have comparable academic performances to their peers with native-born parents is a testament to Canada's strong political commitment when it comes to social integration (Bloemraad 2012; Li, 2003). Canada is one of the few countries that has made progress pertaining to the integration of immigrant students as well as addressing educational inequalities in this regard (Simich, Beiser, Stewart \& Mwakarimba, 2005; Shakya, Guruge, Hynie, Akbari, Malik, Htoo, ... Alley, 2010). The second hypothesis, which adds depth to the first, refers to the student's parental characteristics and the selection policies to which immigrants are subjected. Certain studies show that Canada is one of the countries that selects immigrants based on their educational and economic capital (Belot \&, Hatton, 2008; Lowell, 2005). Therefore, while recognizing that immigration policies favor the educational success of immigrant youth, some authors such as Boyd (2002), Rothon, Heath and Lessard-Phillips (2009), Hochschild and Cropper (2010) argue that this success is largely attributable to the qualities of the immigrants themselves. This finding is made particularly apparent through the works of Mc Andrew (2015) in the province of Quebec. Similar results were also found in the United States (Feliciano, 2005).

However, it is necessary for these interpretions to be nuanced, given that certain ethnic immigrant communities that are racialized (socially assigned a racial identity) still face mitigated forms of segregation (Henry \& Tator, 2009, 2010). In Quebec, recent studies (Mc Andrew et al., 2008, 2013; Potvin \& Leclerq, 2011) have identified the regional origins of youth at risk of learning difficulties and special education, and for whom dropout rates are higher in high school compared to the general population: the Caribbean and Sub-Saharan Africa; Central and South America; and South Asia (Mc Andrew et al., 2013). This overrepresentation has an impact on the educational experience of these youth, their aspirations, their self-esteem, their identity, and their sense of belonging to Quebec society. In addition, they are less likely to attend selective private schools than youth from other regions (Mc Andrew, Ledent \& Murdoch, 2011). Finally, they are also more likely to have experienced situations of exclusion and discrimination during their primary and high school education (Lafortune, 2012; Potvin \& Leclerq, 2011), as well as negative experiences with academic advisors during the transition to postsecondary studies, and various sources of constraint pertaining to college access and integration (Collins, 2016). Our study adds that they are less likely to access postsecondary education, especially via linear pathways to university.

Overall, the results of this article substantiate the results of previous studies in Canada, while adding precisions. The article demonstrates that immigrants access postsecondary education in a higher proportion than non-immigrants, although significant differences exist within immigrant groups, depending on their parental origins. The study, thus shows the similarity between Quebec and other Canadian provinces in terms of immigrant schooling, despite the specificity of the organization of the educational system in this province. Beyond this, its contribution is to have identified both similarities and differences in educational pathways, as well as educational inequalities that are characteristic of immigrant students according to different parental origins.

\section{Conclusion}

The objective of this study was to describe and understand the postsecondary pathway morphology of young Canadians from the province of Quebec from immigrant background, as well as the factors that contribute to the structuration of their pathways. The results make it possible to draw the conclusions that follow. Firstly, these youth pursue postsecondary education via linear pathways at a higher proportion than their peers whose parents were born in Canada. Secondly, differences are significantly higher at the university level than at the college level. Thirdly, students from immigrant bacgrounds are more likely to undertake a linear pathway to uni versity, with the exception of those whose parents come from Latin America and the Caribbean. Fourthly, there are significant differences among youth from immigrant backgrounds specifically. Access to postsecondary education and the undertaking of linear educational pathways vary according to parental geographic origin and whether the student is a first or second-generation immigrant. In particular, second-generation immigrants from East Asia, and to a lesser extent, those from North Africa and the Middle East are more likely than others to access postsecondary education, to follow a linear pathway to uni versity, and to obtain a diploma ten years after their first year of high school. In contrast, immigrants of Latin American and 
Caribbean origin, whether first or second-generation, are the least likely to access postsecondary education through linear pathways to uni versity and obtain a diploma. Additional analyses reveal that they are proportionally more likely to undertake non-linear pathways, combining vocational or technical training and general education. According to the writings of Duru-Bellat $(1996,2003)$ on the educational and vocational guidance of students from disadvantaged backgrounds, it can be postulated that young people from Latin American and Caribbean origins would be more vulnerable and thus more preoccupied with developping strategies in order to cope with the multiple constraints (economic and academic) to which they are subjected to. Choosing a technical and professional training path to ensure employment and financial security would be realistic, since success is more or less certain. It also constitutes a strategy that allows them to support themselves and handle their own financial obligations when they enter university. This trajectory, which can be described as a "building-block pathway" would allow them to set realistic academic objectives for themselves, which they would be able to fulfill at their own pace.

In sum, despite significant differences in postsecondary education access, pathway morphology tends to be similar between immigrants when educational background in high school is accounted for - the commonality is a linear pathway to uni versity, specifically. In a Canadian context, the results of this article tend to corroborate those of previous studies that have highlighted the increased participation of immigrants in postsecondary education (Finnie \& Mueller, 2010, Picot, 2012), but also reveal significant differences among youth of immigrant backgrounds, acc ording to parental geographic origin (Kamanzi et al., 2016; Thiessen, 2009).

In terms of methodological limitations, three constraints of the database that was used must be underscored. The first is the groupings of parental geographic regions because of the small numbers that emerged solely by country. It is clear that, while being part of the same geographical area, the countries of origin of Canadian immigrants differ from each other and, consequently, these immigrants differentiate among themselves in several aspects that are not without effect on the youth's educational pathways (Levels, Dronkers \& Kraaykamp, 2008). The second is to have confined the analysis to the Montreal region (city of Montreal and its suburbs) for the same reasons. The Montreal re gion differs greatly from the rest of Quebec in its social and economic structure, as well as in the configuration of its network of educational institutions and the resulting school supply (diversified school market: regular public schools, public programs with selective programs, private schools, ethno-specific schools, etc.). Therefore, the generalization of the results must be nuanced. The third limitation is the attrition of dropout students. Originally, the database used was created to study the pathways to and within postsecondary education. Students who dropped out of high school were thus excluded as, by definition, access to postsecondary education (college) is conditional upon graduation from high school. While certain communities (notably those from the Caribbean and Sub-Saharan Africa) have high dropout rates in school (Mc Andrew 2015, Mc Andrew et al., 2013), leaving this category unaccounted for runs the risk of overestimating their pathways to postsecondary education. In the same vein, the database used does not contain information on academic results, which also determines pathways and access to postsecondary education.

In spite of these limitations, this study contains interesting social and scientific results and gives way to new research possibilities in public and educational policies. Namely, an understanding of the educational pathways of students from disadvantaged and multiethnic backgrounds. Finally, qualitative studies would further contribute to a better understanding of these pathways and the dimensions that play a role in their structuration.

\section{References}

Abada, T., Hou, F., \& Ram, B. (2009). Ethnic differences in educational attainment among the second generation of immigrants. Canadian Journal of Sociology, 34(1), 1-28.

Allison, P. D. (2003). Logistic Regression. Using the SAS System. Theory and Application. Cary, NC: SAS Institute Inc.

Alon, S. (2009). The evolution of class inequality in higher education: competition, exclusion, and adaptation. American Sociological Review, 74, 731-755. https://doi.org/10.1177/000312240907400503

Anisef, P. S., Brown, R., \& Sweet, R. (2011). Post-secondary pathway choices of immigrant and native-born youth in Toronto. Canadian Issues, Winter 2011, 42-48.

Barrett, A., \& Maître, B. (2013). Immigrant welfare receipt across Europe. International Journal of Manpower, 34(1), 8-23. https://doi.org/10.1108/01437721311319629

Baum, S., \& Flores, S. M. (2011). Higher Education and Children in Immigrant Families. The Future of Children, 21(1), 171-193. https://doi.org/10.1353/foc.2011.0000

Belot, M., \& Hatton, T. (2008). Immigrant selection in the OECD. CEPR Working Paper No. 6675.

Bloemraad, I. (2012). Understanding "Canadian Exceptionalism" in Immigration and Pluralism Policy. Washington, DC: Migration Policy Institute. 
Boyd, M. (2002). Educational offspring: success or segmented assimilation? International Immigration Review, 36(4), 1036-1060.

Collins, T. (2016). Postsecondary Pathways Among Second-Generation Immigrants of Haitian Origin: A Montreal CEGEP Case Study (Unpublished master's thesis). University of Montreal Montreal,. Canada.

Crul, M., Schneider, J., \& Lelie, F. (Eds.). (2012). The European Second Generation Compared Does the Integration Context Matter? Netherlands, Amsterdam: Amsterdam University Press.

Crul, M., Schnell, P., Herzog-Punzenberger, B., Wilmes, M., Slootman, M., \& Gómez, R.A. (2012). School careers of second-generation youth in Europe: Which education systems provide the best chances for success? Crul, M., Schneider, J., \& Lelie, F. (Eds.), The European Second Generation Compared Does the Integration Context Matter? Netherlands, Amsterdam: Amsterdam University Press, 110-165.

Cutler, D. M., Glaeser, E. L., \& Vigdor, J. L. (2007). When Are Ghettos Bad? Lessons From Immigrant Segregation in The United States. Working Paper 13082, Cambridge, National Bureau Of Economic Research. https://doi.org/10.3386/w13082

Duru-Bellat, M. (1996). Social inequalities in French secondary schools: From figures to theories. British Journal of Sociology of Education, 17(3), 341-350. https://doi.org/10.1080/0142569960170307

Duru-Bellat, M. (2003). Inégalités sociales à l'école et politiques éducatives. Paris: Unesco, Institut international de planification de l'éducation.

Duru-Bellat, M., Kieffer, A., \& Reimer, D. (2010). Les inégalités d'accès à l'enseignement supérieur : le rôle des filières et des spécialités. Une comparaison entre l'Allemagne de l'Ouest et la France. Économie et statistique, 433(1), 3-22. https://doi.org/10.3406/estat.2010.8082

Dustmann, C., Frattini, T., \& Lanzara, G. (2011). Educational achievement of second-generation immigrants: An international comparison, Discussion paper. London, Centre for Research and Analysis of Migration, Department of Economics.

Ellen, I., O'Regan, K., Schwartz, A., Stiefel, L., Neal, D., \& Nechyba, T. (2002). Immigrant children and New York City Schools: Segregation and its consequences [with comments]. Brookings-Wharton Papers on Urban Affairs, 183-214. https://doi.org/10.1353/urb.2002.0003

Feliciano, C. (2005). Does selective migration matter? Explaining ethnic disparities in educational attainment among immigrants' children. International Migration Review, 39(4), 841-871. https://doi.org/10.1111/j.1747-7379.2005.tb00291.x

Felouzis, G. (2014). Les inégalités scolaires. Paris, Presses universitaires de France.

Felouzis, G., Liot, F., \& Perroton, J. (2005). L'apartheid scolaire : enquête sur la ségrégation ethnique dans les collèges . Paris, France: Éditions du Seuil.

Finnie, R., \& Mueller, R. E. (2008). The effects of family income, parental education and other background factors to postsecondary education in Canada. Measuring the effectiveness of student aid, MESA project paper. Toronto, Canada: Educational Policy Institute.

Finnie, R., \& Mueller, R. E. (2010). They came, they saw, they enrolled: Access to post-secondary education by the children of Canadian immigrants. In Finnie, R, Frenette, M., Mueller, R.E, Sweetman, A. (Eds.), Pursuing higher education in Canada: Economic, Social, and Policy Dimen sions. Kingston, Queen's University Press, 192-216.

Griga, D., \& Hadjar, A. (2013). Migrant Background and Higher Education Participation in Europe: The Effect of the Educational Systems. European Sociological Review, 30(3), 275-286. https://doi.org/10.1093/esr/jct031

Henry, F., \& Tator, C. (2009). The colour of democracy : racism in Canadian society. ( $4^{\text {th }}$ ed.). Toronto, Canada: Nelson Education.

Henry, F., \& Tator, C. (2010). Racism in the Canadian university. Demanding social justice, inclusion, and equity. Toronto, Canada: University of Toronto Press.

Hochschild, J. L., \& Cropper, P. (2010). Immigration regimes and schooling regimes: Which countries promote successful immigrant incorporation? Theory and Research in Education, 8(1), 21-61. https://doi.org/10.1177/1477878509356342

Hoelscher, M., Hayward, G. E., Dunbar, H., \& Goddet, H. (2008). The transition from vocational education and training to higher education: a successful pathway? Research Papers in Education, 23(2), 139-151. https://doi.org/10.1080/02671520802048679 
Jenkins, S. P., Micklewright, J., \& Schnepf, S.V. (2008). Social segregation in secondary schools: how does England compare with other countries? Oxford Review of Education, 34(1), 21-37. https://doi.org/10.1080/03054980701542039

Kamanzi, P. C., \& Murdoch, J. (2011). L'accès à un diplôme universitaire chez les immigrants. In Kanouté, F., Lafortune, G. (Eds.), Familles québécoises d'origine immigrante: les dynamiques de l'établissement. Montréal, Canada: Presses de l'Université de Montréal, 145-158.

Kamanzi, P. C., Bastien N., Doray, P., \& Magnan, M. O. (2016). Immigration et cheminements scolaires aux études supérieures au Canada: qui y va et quand? Une analyse à partir du modèle de risque proportionnel de Cox. Canadian Journal of Higher Education, 46(2), 209-232.

Kamanzi, P. C., Guegnard, C., Imdorf, C., Koomen, M., \& Murdoch, J. (2014). Démocratisation de l'enseignement supérieur et emprise des parcours : comparaison entre la France, la Suisse et le Canada. Télescope, 20(2), 170-188.

Koopmans, R. (2010). Trade-Offs between Equality and Difference: Immigrant Integration, Multiculturalism and the Welfare State in Cross-National Perspective. Journal of Ethnic and Migration Studies. 36(1), 1-26. https://doi.org/10.1080/13691830903250881

Lafortune, G. (2012). Rapport à l'école et aux savoirs scolaires de jeunes d'origine haïtienne en contexte scolaire défavorisé à Montréal (Unpublished doctoral dissertation). University of Montreal, Montreal, Canada.

Levels, M., Dronkers, J., \& Kraaykamp, G. (2008). Immigrant children's educational achievement in western countries: origin, destination, and community effects on mathematical performance. American Sociological Review, 73, 835-853. https://doi.org/10.1177/000312240807300507

Li, P. S. (2003). Deconstructing Canada's discourse of immigrant integration. Journal of International Migration and Integration, 4(3), 315-333. https://doi.org/10.1007/s 12134-003-1024-0

Lowell, B. L. (2005). Policies and regulations for managing skilled international migration for work. New York, NY: United Nations, Population Division Department of Economic and Social Affairs United Nations Secretariat.

Lucas, S. L. (2001). Effectively maintained inequality: education transitions, track mobility, and social background effects. American Journal of Sociology, 106(6), 1642-1690. https://doi.org/10.1086/321300

Lynch, K., \& O'Riordan, C. (1998). Inequality in higher education: A study of class barriers. British Journal of Sociology of Education, 19(4), 445-478. https://doi.org/10.1080/0142569980190401

Maclean, R., \& Pavlova, M. (2013). Vocationalization of secondary and higher education: pathways to the world of work. In UNESCO-UNEVOC International Centre for Technical and Vocational Education and Training (Eds.), Revisiting global trends in TVET: Reflections on theory and practice Bonn, Germany: UNESCO-UNEVOC, $\mathrm{p}$. 40-84.

Mc Andrew, M. (2015). La réussite éducative des élèves issus de l'immigration : dix ans de recherches et d'intervention. Montreal, Canada : Presses de l'Université de Montréal. https://doi.org/10.4000/books.pum.3005

Mc Andrew, M., Garnett, B., Ledent, J., \& Ungerleider, C. (2008). La réussite scolaire des élèves issus de l'immigration : une question de classe sociale, de langue ou de culture ? Éducation et culture, 36(1), 177-196. https://doi.org/10.7202/018096ar

Mc Andrew, M., Ledent, J., Murdoch, J., \& Ait-Saïd, R. (2011). La réussite scolaire des élèves issus de l'immigration au secondaire, Final report. Montreal, Canada: Ministère de l’Éducation, du Loisir et du Sport du Québec.

Mc Andrew, M., Ledent, J., Murdoch, J., Ait-Said, R., \& Balde, A. (2013). Le profil et le cheminement scolaire des jeunes Québécois issus de l'immigration au secondaire: Un portrait statistique. Cahiers québécois de démographie, 42(1), 31-55. https://doi.org/10.7202/1017097ar

Murdoch, J., Guégnard, G., Koomen, M., Imdorf, C. Kamanzi, C., \& Meyer, T. (2017). Pathways fostering mobility to higher education for vulnerable immigrants in France, Switzerland and Canada. European Journal of Higher Education, 7(1), 29-42.https://doi.org/10.1080/21568235.2017.1254918

Pechar, H., \& Andres, L. (2011). Higher-education policies and welfare regimes: International comparative perspectives, Higher Education Policy, 24(1), 25-52. https://doi.org/10.1057/hep.2010.24

Phinney, J. S., Horenczyk, G, Liebkind, K., \& Vedder, P. (2001). Ethnic identity, immigration, and well-being : an interaction Perspective. Journal of Social Issues, 57(3), 493-510. https://doi.org/10.1111/0022-4537.00225

Picard, F., Trottier, C., \& Doray, P. (2011). Conceptualiser les parcours scolaires à l'enseignement supérieur. L'orientation scolaire et professionnelle, 40(3), 1-19. https://doi.org/10.4000/osp.3531 
Picot, G. (2012). Immigrant status and secondary school performance as determinants of post-secondary participation: A Comparison of Canada and Switzerland. OECD Education Working Paper, $\mathrm{n}^{\circ}$ 77. Paris, France: OECD Publishing. https://doi.org/10.1787/5k9909jhz4wl-en

Potvin, M., \& Leclercq, J. B. (2011). Étude exploratoire sur les trajectoires sociales et scolaires de jeunes de 16-24 ans issus de l'immigration en formation générale aux adultes à Montréal. Canadian Issues, Winter 2011, 35-41.

Riedel, A., Schneider, K., Schuchart, C., \& Weishaupt, H. (2010). School choice in German primary schools: How binding are school districts? Journal for Educational Research Online, 2(1), 94-120.

Rothon, C., Heat, A., \& Lessard-Philips, L. (2009). The educational attainments of the second generation : A Comparative study of Britain, Canada, and the United States. Teachers College Record, 111(6), 1404-1443.

Schnepf, S. V. (2007). Immigrants' educational disadvantage: an examination across ten countries and three surveys. Journal of Population Economics, 20(3), 527-545. https://doi.org/10.1007/s00148-006-0102-y

Shakya, Y. B., Guruge, S., Hynie, M., Akbari, A., Malik, M., Htoo, S., ... Alley, S. (2010). Aspirations for higher education among newcomer refugee youth in Toronto: Expectations, challenges, and strategies. Refuge: Canada's Periodicalon Refugees, 27(2), 65-78.

Simich, L., Beiser, M., Stewart, M., \& Mwakarimba, E. (2005). Providing social support for immigrants and refugees in Canada: Challeges and directions. Journal of Immigrant Health, 7(4), 259-268. https://doi.org/10.1007/s 10903-005-5123-1

Söhn, J., \& Özcan, V. (2006). The Educational Attainment of Turkish Migrants in Germany. Turkish Studies, 7(1), 101-124. https://doi.org/10.1080/14683840500520626

Taylor, A., \& Krahn, H. (2005). Aiming high: Educational aspirations of visible minority immigrant youth. Canadian Social Trends, 79, 8-12.

Thiessen, V. (2009). The pursuit of postsecondary education: A comparison of First Nations, African, Asian, and European Canadian Youth. Canadian Review of Sociology, 46(1), 5-37. https://doi.org/10.1111/j.1755-618X.2009.01201.x

Zulfikar, T. (2016). "I feel different though": Narratives of young Indonesian Muslims in Australian public schools. International \& Comparative Education, 3, 1-15. https://doi.org/10.1080/2331186X.2016.1139767

\section{Copyrights}

Copyright for this article is retained by the author(s), with first publication rights granted to the journal.

This is an open-access article distributed under the terms and conditions of the Creative Commons Attribution license which permits unrestricted use, distribution, and reproduction in any medium, provided the original work is properly cited. 